\title{
ANALISIS FAKTOR PEMILIHAN LOKASI USAHA JASA PADA UMKM DI KECAMATAN PACIRAN
}

\author{
Ariffa Tio Hanggita \\ Department of Management FEB UMM \\ E-mail: artioh18@gmail.com
}

\begin{abstract}
The aim of this study was to examine the most considered factor in selecting business place for Small and Medium Business Scale Empowerment (UMKM) in Paciran. The data were analyzed by using factor analysis. The results of the study showed that there were 3 considered factors in selecting business place, namely human resources \& tax, power, and access. Based on factor analysis, the most considered factor in selecting business place in Paciran was human resources \& $\operatorname{tax}(34.278 \%)$.
\end{abstract}

Keywords: factor analysis, place factor, service factor

\section{PENDAHULUAN}

Dalam upaya mendapatkan konsumen sebanyak mungkin, ada beberapa faktor yang harus diperhatikan oleh pengusaha. Salah satu faktor tersebut adalah pemilihan lokasi. Dari beberapa pilihan lokasi usaha, pengusaha diharuskan untuk jeli dalam memilih lokasi karena hal ini berdampak pada proses berjalannya usaha. Tjiptono (2008) menjelaskan bahwa lokasi adalah tempat usaha beroperasi atau tempat usaha melakukan kegiatan untuk menghasilkan barang dan jasa yang mementingkan segi ekonominya.

Pemilihan lokasi usaha dipengaruhi beberapa faktor berbeda penerapannya bagi satu usaha dengan usaha yang lain, sesuai produk dan jasa yang dihasilkan. Ketepatan dalam pemilihan lokasi merupakan salah satu faktor yang dipertimbangkan oleh pelaku usaha sebelum membuka usahanya.
Pemilihan lokasi yang strategis dan dekat dengan konsumen ataupun pasar akan mempengaruhi sukses atau tidaknya suatu usaha. Handoko (2000) menyatakan bahwa kesalahan-kesalahan di dalam pemilihan lokasi untuk membangun atau mendirikan harus diminimalkan sehingga industri/usaha yang didirikan tersebut dapar beroperasi secara efektif dan efisien.

Jadi, alasan utama terjadinya perbedaan dalam pemilihan lokasi adalah adanyaperbedaan kebutuhan masing-masing perusahaan. Lokasi yang baik adalah persoalan individual. Hal ini sering disebut dengan pendekatan "situasional / contingency" untuk pembuatan keputusan. Bila dinyatakan secara sederhana, semuanya bergantung.

Usaha Mikro, Kecil dan Menengah adalah usaha produktif milik orang perorangan atau badan usaha perorangan yang memenuhi 
kriteria dari tiap kategori. Hal ini diatur berdasarkan Undang Undang Nomor 20 tahun 2008 tentang Usaha Mikro Kecil dan Menengah. Ciri-ciri UMKM adalah manajemen berdiri sendiri, daerah pemasarannya lokal, aset usahanya kecil, jumlah karyawan yang terbatas.

Menurut Chase, et al (2006) keputusan pemilihan lokasi usaha manufakturdan usaha jasa dipengaruhi oleh berbagai macam kriteria pemilihan yangmendasarkan pada kepentingan kompetitif. Diantara kriteria pemilihan tersebutadalah jarak ke pelanggan, iklim bisnis, total biaya yang harus dikeluarkan,infrastruktur, kualitas tenaga kerja, suplier, lingkungan masyarakat, dan pengaruhpajak.

I Wayan Sastrawan (2015) melakukan penelitian dengan tujuan untuk mengetahui faktor yang paling dominan dalam pemilihan lokasi usaha PKL adalah akses, visibilitas, lalu lintas, tempat parkir, ekspansi, lingkungan, persaingan dan peraturan pemerintah. Alat analisis yang digunakan adalah analisis faktor.

Penelitian ini mencari faktor yang paling dominan diantara kedelapan faktor tersebut. Diketahui faktor yang paling dominan adalah faktor akses dengan eigenvalue sebesar 56,331\%. Sri Zuliarni dan Relon Taufik Hidayat, meneliti seberapa penting faktor lokasi usaha. Alat analisis yang digunakan disini adalah analisis deskriptif. Subvariabel yang digunakan dalam penelitian ini adalah akses, visibilitas, tempat parkir, lingkungan dan persaingan.

Hasil dari penelitian menunjukkan bahwa faktor yang sangat penting dalam pemilihan lokasi usaha adalah akses, visibilitas, lingkungan, dan tempat parkir. Sementara faktor lain yang dianggap penting bagi pemilik usaha adalah persaingan. Pada penerapannya di dunia nyata, faktor yang dipertimbangkan dalam pemilihan lokasi untuk suatu usaha dengan usaha lain berbeda dengan teori-teori yang dikemukakan oleh pencetus toeri lokasi. Karena semua bergantung dengan usaha yang dijakankan oleh pengusaha masingmasing. Dengan berjalannya waktu, kebutuhan akan lokasi usaha semakin tinggi sedangkan persaingan antar usaha semakin ketat.

Penelitian ini memiliki tujuan untuk mencari apakah faktor yang diangkat peneliti yaitu 7 faktor yang telah ditentukan yaitu tenaga kerja, akses, fasilitas, pasar, energi, persaingan, dan peraturan pemerintah yang dijadikan subvariabel menjadi pertimbangan dalam pemilihan lokasi usaha dan faktor apakah yang paling dipertimbangkan dalam pemilihan lokasi usaha jasa yang ada di Kecamatan Paciran, Kabupaten Lamongan.

\section{TINJAUAN PUSTAKA}

Menurut Tarigan (2006), teori lokasi adalah ilmu yang menyelidiki tata ruang (spatial order) kegiatan ekonomi, atau ilmu yang menyelidiki alokasi geografis dari sumbersumber yang potensial, serta hubungannya dengan atau pengaruhnya terhadap keberadaan berbagai macam usaha/kegiatan lain baik ekonomi maupun sosial.

Lokasi berhubungan dengan di mana usaha harus bermarkas dan melakukan operasi atau kegiatannya (Lupiyoadi, 2009). Pemilihan lokasi 
harus mempertimbangkan berbagai aspek yang tentunya diarahkan untuk mendorong penjualan dan memberikan keuntungan bagi usaha. Pemilihan lokasi usaha dipengaruhi oleh beberapa faktor. Faktor-faktor ini pada prakteknya berbeda penerapannya bagi satu usaha dengan usaha yang lain, sesuai dengan produk dan jasa yang dihasilkan.

Menurut Tjiptono (2007) pemilihan tempat atau lokasi usaha memerlukan pertimbangan yang cermat terhadap beberapa faktor berikut: Akses, Visibilitas, Lalu lintas, Tempat parkir, Ekspansi, Lingkungan, Persaingan, dan Peraturan pemerintah. Sedangkan Hindrayani (2010) menjelaskan bahwa faktor-faktor yang mempengaruhi pemilihan lokasi usaha seperti letak konsumen atau pasar, sumber bahan baku, sumber tenaga kerja, air dan listrik, transportasi, lingkungan masyarakat dan sikap yang muncul, peraturan pemerintah, pembuangan limbah industri, fasilitas pabrik dan karyawan. Dari beberapa teori yang telah dicantumkan diatas maka kerangka pikir yang digunakan adalah sebagai berikut:

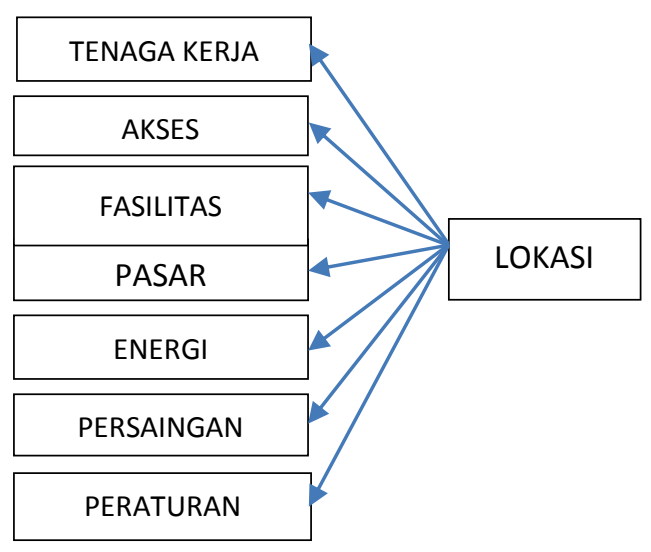

Gambar 1. Kerangka Pikir Penelitian

\section{METODE PENELITIAN}

Jenis penelitian ini yaitu penelitian deskriptif kuantitatif. Dalam penelitian ini yang menjadi populasi adalah pemilik (owner) usaha jasa yang berada di Paciran, Lamongan yang berjumlah 160 unit usaha. Peneliti menggunakan metode non problability sampling yaitu judgmental sampling.

Widayat (2004) menjelaskan judgemental sampling yaitu pengambilan sampel berdasarkan penilaian peneliti mengenai siapasiapa saja yang pantas untuk dijadikan sampel dalam penelitian. Kriteria dalam pengambilan sampel ialah usaha dengan ciri-ciri UMKM yang bergerak pada bidang usaha jasa dan telah berdiri minimal 6 bulan. Definisi operasional variabel lokasi dibagi menjadi 7 sesuai dengan faktor yang diangkat dan indikator yang digunakan dalam penelitian guna mengetahui rumusan yang diangkat. Tenaga kerja dengan indikator pendidikan tenaga kerja, budaya tenaga kerja, jumlah tenaga kerja, kemudahan memperoleh tenaga kerja, murahnya gaji.

Subvariabel akses dengan indikator kemudahan untuk menuju lokasi dan mudah dijangkau sarana transportasi. Subvariabel fasilitas dengan indikator lahan parkir, tingkat keamanan dan kesesuaian harga dengan kondisi fisik.

Subvariabel pasar dengan indikator jumlah penduduk di daerah sekitar lokasi, tingkat pendapatan di daerah sekitar lokasi dan daya beli konsumen. Dalam subvariabel energi dengan indikator ketersediaan listrik dan ketersediaan air.

Dalam subvariabel persaingan dengan indikator jarak dengan usaha 
yang sebidang dan diferensiasi harga jasa. Dalam subvariabel peraturan pemerintah dengan indikator kemudahan perizinan, insentif pemerintah dan pajak.

Pengukuran yang digunakan dalam penelitian ini adalah rentang skala dan ukuran interval. Skala yang digunakan dalam penelitian ini adalah skala likert 5 titik untuk menelaah seberapa kuat subjek setuju atau tidak dengan pertanyaan yang diajukan oleh peneliti.

Dengan acuan poin 5 adalah sangat penting dan poin 1 adalah sangat tidak penting. Dalam penelitian ini rentang skala digunakan untuk mengetahui nilai indikator tiap subvariabel yang dipertimbangkan dalam pemilihan lokasi dengan menggunakan rumus rentang skala yang dinyatakan oleh Umar (2008), yang mana Rs adalah rentang skala, $\mathrm{n}$ adalah jumlah sampel, $m$ adalah jumlah alternatif jawaban, sebagai berikut:

$$
R S=\frac{n(m-1)}{m}
$$

Berdasarkan perhitungan rentang skala diperoleh sebesar 80. Dengan demikian skala penelitian setiap kriteria tertera pada Tabel 1 sebagai berikut:

Tabel 1. Rentang Skala Untuk Indikator Subvariabel

\begin{tabular}{cccc}
\hline Rentang Skala & Tenaga Kerja & --- & $\begin{array}{c}\text { Peraturan } \\
\text { Pemerintah }\end{array}$ \\
\hline $100-180$ & Sangat Tidak & Sangat Tidak & Sangat Tidak \\
Penting \\
$181-260$ & Penting & Penting & Tidak Penting \\
$261-340$ & Tidak Penting & Tidak Penting & Cukup \\
$341-420$ & Penting & Cukup & Penting \\
$421-500$ & Sangat Penting & Penting & Sangat Penting \\
\hline
\end{tabular}

Ukuran interval adalah skala yang sama seperti nominal dan ordinal namun mempunyai karakteristik tetap dan dapat dinotasikan dalam fungsi matematika. Skala interval menentukan perbedaan, urutan dan kesamaan besaran perbedaan tiap variabel (Sekaran 2006). Selanjutnya adalah penentuan ukuran interval untuk masing-masing subvariabel dan untuk variabel lokasi.
Pertama, untuk subvariabel tenaga kerja maka perhitungan Nilai indeks min = skor min $\mathrm{x}$ jumlah item pertanyaan $\mathrm{x}$ jumlah responden yaitu, 300. Nilai indeks maks $=$ skor maks $\mathrm{x}$ jumlah item pertanyaan $\mathrm{x}$ jumlah responden, sehingga nilai indeks maks 1500. Interval = nilai indeks maks - nilai indeks min, sehingga intervalnya adalah 1200 . Jarak Interval = Interval $:$ jenjang interval, maka jaraknya adalah 240 .

Tabel 2. Ukuran Interval Subvariabel Tenaga Kerja

\begin{tabular}{cccccc}
\hline Sangat Penting & Tidak penting & Cukup & Penting & Sangat Penting \\
\hline 500 & 900 & 1300 & 1700 & 2100 & 2500 \\
\hline
\end{tabular}

Kedua, subvariabel akses, energi dan persaingan. Untuk nilai indeks $\min =$ skor $\min \mathrm{x}$ jumlah item pertanyaan $\mathrm{x}$ jumlah responden maka 
hasilnya 300. Nilai indeks maks = skor maks $\mathrm{x}$ jumlah item pertanyaan $\mathrm{x}$ jumlah responden sehingga hasilnya adalah 1500. Interval = nilai indeks maks - nilai indeks min, maka hasilnya 1200. Jarak Interval = Interval : jenjang interval, sehingga jarak intervalnya 240.

Tabel 3. Ukuran Interval Subvariabel Akses, Energi dan Persaingan

\begin{tabular}{cccccc}
\hline Sangat Penting & Tidak penting & Cukup & Penting & \multicolumn{2}{l}{ Sangat Penting } \\
\hline 200 & 360 & 520 & 680 & 840 & 1000 \\
\hline
\end{tabular}

Ketiga, subvariabel fasilitas, pasar dan kebijakan pemerintah. Untuk nilai indeks $\min =$ skor $\min \mathrm{x}$ jumlah item pertanyaan $\mathrm{x}$ jumlah responden maka hasilnya 300 . Nilai indeks maks $=$ skor maks $\mathrm{x}$ jumlah item pertanyaan $\mathrm{x}$ jumlah responden sehingga hasilnya adalah 1500 . Interval $=$ nilai indeks maks - nilai indeks min, maka hasilnya 1200. Jarak Interval $=$ Interval $:$ jenjang interval, maka hasilnya 240.

Tabel 4. Ukuran Interval Subvariabel Fasilitas, Pasar, dan Kebijakan Pemerintahan

\begin{tabular}{cccccc}
\hline Sangat Penting & Tidak penting & Cukup & Penting & \multicolumn{2}{c}{ Sangat Penting } \\
\hline 300 & 540 & 780 & 1020 & 1260 & 1500 \\
\hline
\end{tabular}

Keempat, variabel lokasi. Untuk nilai indeks $\min =$ skor min $\mathrm{x}$ jumlah item pertanyaan $\mathrm{x}$ jumlah responden maka hasilnya 2000. Nilai indeks maks = skor maks $\mathrm{x}$ jumlah item pertanyaan $\mathrm{x}$ jumlah responden sehingga hasilnya adalah 10000 . Interval $=$ nilai indeks maks - nilai indeks min, maka hasilnya 8000 . Jarak Interval $=$ Interval $:$ jenjang interval, maka jarak intervalnya adalah 1600 .

Tabel 5. Ukuran Interval Variabel

\begin{tabular}{cccccc}
\hline Sangat Penting & Tidak penting & Cukup & Penting & \multicolumn{2}{c}{ Sangat Penting } \\
\hline 2000 & 3600 & 5200 & 6800 & 8400 & 10000 \\
\hline
\end{tabular}

Uji validitas adalah metode yang menunjukkan sejauh mana alat pengukur itu mengukur apa yang ingin diukur. Uji validitas instrumen dilakukan dengan membandingkan nilai $r$ hasil dengan nilai $r$ tabel dengan derajat bebas (n-2).

Apabila dibandingkan, nilai $r$ hasil perhitungan $>$ dari nilai $r$ dalam tabel pada alfa tertentu maka dapat disimpulkan bahwa butir pertanyaan itu valid. Apabila $r$ hasil < daripada $r$ tabel maka data dikatakan tidak valid (Sanusi 2011). Arikunto (2003) mengatakan realibilitas menunjukan tingkat keandalan sesuatu. Pengujian reliabilitas instrument menggunakan rumus Cronbach's Alpha. Ghozali (2005) mengatakan bahwa instrumen dikatakan reliabel, jika nilai Cronbach's Alpha $=0.60$

Analisis faktor adalah teknik yang digunakan untuk mencari faktor yang menjelaskan hubungan atau korelasi antara berbagai indikator independen yang diobservasi (Hidayat, 2014). Tujuan analisis faktor adalah untuk menjelaskan 
struktur hubungan di antara banyak variabel dalam bentuk faktor. Langkah-langkah analisis faktor adalah dengan validasi analisis faktor, jumlah faktor yang terbentuk, menamakan faktor, dan faktor yang berpengaruh dominan.

\section{HASIL PENELITIAN DAN PEMBAHASAN}

Berikut adalah hasil uji validitas dan reliabilitas yang telah diolah dengan aplikasi SPSS 23 ditunjukkan oleh Tabel 6 dan Tabel 7.

Tabel 6. Hasil Uji Validitas Variabel Lokasi

\begin{tabular}{|c|c|c|c|c|c|}
\hline Variabel & Subvariabel & Item & $\mathrm{R}_{\text {hitung }}$ & $\mathrm{R}_{\text {tabel }}$ & Ket. \\
\hline \multirow[t]{20}{*}{ Lokasi } & \multirow{5}{*}{ Tenaga Kerja } & $\mathrm{X} 1$ & 0.594 & 0.1966 & Valid \\
\hline & & $\mathrm{X} 2$ & 0.445 & 0.1966 & Valid \\
\hline & & X3 & 0.674 & 0.1966 & Valid \\
\hline & & $\mathrm{X} 4$ & 0.425 & 0.1966 & Valid \\
\hline & & $\mathrm{X} 5$ & 0.357 & 0.1966 & Valid \\
\hline & \multirow{3}{*}{ Akses } & X6 & 0.719 & 0.1966 & Valid \\
\hline & & $\mathrm{X} 7$ & 0.804 & 0.1966 & Valid \\
\hline & & $\mathrm{X} 8$ & 0.656 & 0.1966 & Valid \\
\hline & \multirow[t]{2}{*}{ Fasilitas } & $\mathrm{X} 9$ & 0.529 & 0.1966 & Valid \\
\hline & & X10 & 0.495 & 0.1966 & Valid \\
\hline & \multirow{3}{*}{ Pasar } & $\mathrm{X} 11$ & 0.689 & 0.1966 & Valid \\
\hline & & $\mathrm{X} 12$ & 0.613 & 0.1966 & Valid \\
\hline & & $\mathrm{X} 13$ & 0.675 & 0.1966 & Valid \\
\hline & \multirow{2}{*}{ Energi } & X14 & 0.804 & 0.1966 & Valid \\
\hline & & $\mathrm{X} 15$ & 0.859 & 0.1966 & Valid \\
\hline & \multirow{2}{*}{ Persaingan } & $\mathrm{X} 16$ & 0.756 & 0.1966 & Valid \\
\hline & & $\mathrm{X} 17$ & 0.678 & 0.1966 & Valid \\
\hline & \multirow{3}{*}{$\begin{array}{c}\text { Peraturan } \\
\text { Pemerintah }\end{array}$} & $\mathrm{X} 18$ & 0743 & 0.1966 & Valid \\
\hline & & X19 & 0.701 & 0.1966 & Valid \\
\hline & & $\mathrm{X} 20$ & 0.756 & 0.1966 & Valid \\
\hline
\end{tabular}

Berdasarkan hasil Tabel 6 diatas menunjukkan bahwa semua indikator pada subvariabel menunjukkan valid dikarenakan nilai $\mathrm{r}_{\text {hitung }}$ lebih besar dari 0,1966 atau $r_{\text {hitung }}>r_{\text {tabel }}$. Hasil ini menunjukkan bahwa semua pernyataan variabel lokasi dalam kuesioner yang diajukan kepada responden dapat digunakan untuk mengukur faktor yang mempengaruhi pemilihan lokasi usaha jasa.

Uji reliabilitas digunakan untuk melihat tingkat konsistensi variabel yang ada. Hasil perhitungan dengan SPSS 23 didapatkan data sebagai berikut:
Tabel 7 Uji Reliabilitas

\begin{tabular}{cc}
\hline $\begin{array}{c}\text { Cronbachs } \\
\text { Alpha }\end{array}$ & N of Items \\
\hline 0.628 & 20 \\
\hline
\end{tabular}

Dari tabel diatas dapat diketahui bahwa nilai Cronbach's Alpha> 0,60. Jadi, dapat disimpulkan bahwa data reliabel. Untuk mengetahui faktor yang paling dipertimbangkan dilakukan dengan menggunakan analisis faktor dengan mengukur validasi analisis factor melalui kecukupan sampel dalam penelitian dengan menggunakan Bartlett's Test of Sphericity, Koefisien KaiserMeyer-Olkin (KMO), Measures 
Sampling Adequacy (MSA) dan Comunallities.

Pada pengujian pertama, ada 7 indikator tidak memenuhi syarat MSA > 0,5. Hal ini berarti harus dilakukan pengujian ulang dengan mengeluarkan indikator yang tidak memenuhi syarat. Pada pengujian kedua didapatkan hasil MSA $<0,5$ tetapi ada 6 indikator yang comunalitiesnya $>0,5$ dan nilai initial eigenvalues comulativesdari kurang dari $60 \%$.Hal ini berarti harus dilakukan pengujian ulang.

Setelah melalui 2 (dua) kali proses reduksi, maka proses reduksi dihentikan karena seluruh syarat validasi didapatkan.

Tabel 8: Hasil untuk Pengujian KMO dan Bartlett's Test of Sphericity

\begin{tabular}{lcc}
\hline \multicolumn{2}{c}{ Jenis Pengukuran } & Skor \\
\hline Kaiser-Meyer-Olkin Measure of Sampling Adequacy. & .697 \\
Bartlett's Test of Sphericity & Approx. Chi-Square & 119.220 \\
& df & 21 \\
& Sig. & .000 \\
\hline
\end{tabular}

Berdasarkan tabel 8 diketahui bahwa hasil KMO sebesar 0.697. Ini berarti analisis faktor tepat digunakan untuk menganalisis data yang diperoleh. Hasil uji Bartlett's Test of Sphericity menunjukan hasil 119.220 dengan signifikasi sebesar 0,000 .

Tabel 9: Anti-Image Matrices

\begin{tabular}{|c|c|c|c|c|c|c|c|c|}
\hline & & & & & & & & \\
\hline \multirow{8}{*}{$\begin{array}{l}\text { Anti-image } \\
\text { Covariance }\end{array}$} & & & & & & & & \\
\hline & XI & .658 & -.174 & .027 & .082 & -.164 & -.049 & -.171 \\
\hline & X3 & -.174 & .696 & -.140 & .134 & -.028 & -.067 & -.179 \\
\hline & X6 & .027 & -.140 & .865 & -.136 & .102 & .172 & .049 \\
\hline & X10 & .082 & .134 & -.136 & .801 & -.180 & -.101 & .135 \\
\hline & X14 & -.164 & -.028 & .102 & -.180 & .716 & -.214 & -.026 \\
\hline & X15 & -.049 & -.067 & 172 & -.101 & -.214 & .737 & -085 \\
\hline & X20 & -.171 & -.179 & .049 & .135 & -.026 & -.085 & .679 \\
\hline \multirow{7}{*}{$\begin{array}{l}\text { Anti-image } \\
\text { Correlation }\end{array}$} & X1 & $.756^{\mathrm{a}}$ & -.256 & .036 & .114 & -239 & -.071 & -.255 \\
\hline & X3 & -.256 & $.710^{\mathrm{a}}$ & -.181 & .179 & -.040 & -.094 & -.260 \\
\hline & X6 & .036 & -.181 & $.565^{\mathrm{a}}$ & -.164 & .130 & .216 & .063 \\
\hline & X10 & .114 & .179 & -.164 & $.561^{\mathrm{a}}$ & -.238 & -.132 & .183 \\
\hline & X14 & -.239 & -.040 & .130 & -.238 & $.661^{\mathrm{a}}$ & -.295 & -.038 \\
\hline & X15 & -.071 & -.094 & .216 & -.132 & -.295 & $.710^{\mathrm{a}}$ & -.120 \\
\hline & $\mathrm{X} 20$ & -.255 & -.260 & .063 & .183 & -.038 & -.120 & $.762^{\mathrm{a}}$ \\
\hline
\end{tabular}
faktor yang memenuhi syarat. Faktor itu adalah pendidikan tenaga kerja, budaya tenaga kerja, kemudahan untuk menuju lokasi, harga sewa
Hal ini berarti matriks korelasi yang signifikan dengan sejumlah variabel,

Hasil output SPPS 23 dapat diketahui bahwa pada setiap faktor telah memenuhi syarat MSA > 0,5. Hasil dari masing-masing faktor dapat dilihat pada tabel 9 berikut:

\section{Dari tabel 9, diketahui ada 7}

tempat usaha, ketersediaan listrik, ketersediaan air dan pajak. Faktorfaktor tersebut adalah komponen pembentuk faktor baru. 
Tabel 10. Total Variance Explained

\begin{tabular}{|c|c|c|c|c|c|c|c|c|c|}
\hline \multirow[b]{2}{*}{ Component } & \multicolumn{3}{|c|}{ Initial Eigenvalues } & \multicolumn{3}{|c|}{$\begin{array}{c}\text { Extraction Sums of Squared } \\
\text { Loadings }\end{array}$} & \multicolumn{3}{|c|}{$\begin{array}{c}\text { Rotation Sums of Squared } \\
\text { Loadings }\end{array}$} \\
\hline & Total & $\begin{array}{c}\text { \% of } \\
\text { Variance }\end{array}$ & $\begin{array}{c}\text { Cumulative } \\
\%\end{array}$ & Total & $\begin{array}{c}\text { \% of } \\
\text { Variance }\end{array}$ & $\begin{array}{c}\text { Cumulative } \\
\%\end{array}$ & Total & $\begin{array}{l}\text { \% of } \\
\text { Variance }\end{array}$ & $\begin{array}{c}\text { Cumulative } \\
\%\end{array}$ \\
\hline 1 & 2.399 & 34.278 & 34.278 & 2.399 & 34.278 & 34.278 & 2.110 & 30.140 & 30.140 \\
\hline 2 & 1.440 & 20.573 & 54.852 & 1.440 & 20.573 & 54.852 & 1.595 & 22.779 & 52.919 \\
\hline 3 & 1.006 & 14.369 & 69.220 & 1.006 & 14.369 & 69.220 & 1.141 & 16.301 & 69.220 \\
\hline 4 & .609 & 8.699 & 77.919 & & & & & & \\
\hline 5 & .551 & 7.876 & 85.795 & & & & & & \\
\hline 6 & .510 & 7.288 & 93.083 & & & & & & \\
\hline 7 & .484 & 6.917 & 100.000 & & & & & & \\
\hline
\end{tabular}

Tabel $\quad 10 \quad$ menunjukkan persentase dari faktor satu memiliki eigenvalues sebesar 2.399, faktor dua memiliki eigenvalues sebesar 1.440 sedangkan faktor tiga eigenvalues sebesar 1.006 .

Untuk mengetahui distribusi dimensi-dimensi dapat dilihat pada Tabel 11(Rotated Component Matrix) berikut ini:

Tabel 11. Rotated Component Matrix

\begin{tabular}{cccc}
\multicolumn{4}{c}{ Matrix } \\
\cline { 2 - 4 } Indikator & \multicolumn{3}{c}{ Component } \\
\cline { 2 - 4 } X3 & .802 & .065 & .179 \\
$\mathrm{X} 20$ & .756 & .101 & -.160 \\
$\mathrm{X} 1$ & .721 & .298 & -.070 \\
$\mathrm{X} 14$ & .197 & .795 & -.096 \\
$\mathrm{X} 15$ & .229 & .692 & -.280 \\
$\mathrm{X} 10$ & -.533 & .582 & .388 \\
$\mathrm{X} 6$ & .019 & -.201 & .917 \\
\hline
\end{tabular}

Berdasarkan data pada tabel 11 diatas, maka dapat diketahui komponen faktor pertama terdiri dari X3, X20, X1. Komponen faktor kedua terdiri dari X14, X15 dan X10. Sedangkan X6 masuk dalam komponen faktor ketiga. Ketiga faktor tersebut nantinya akan diberikan nama sesuai dengan indikator/kompenen yang menjadi pembentuk dalam faktor baru yang telah ditemukan.

Ada 2 cara dalam menamakan faktor yang terbentuk yaitu dari komponen yang terbentuk dan pendekatan surrogatte variabel, yaitu memilih salah satu variabel dengan loading faktor tertinggi. Tabel berikut adalah penamaan faktor baru yang telah ditemukan, penjelasan komponen faktor pembentuk dan nilai dari varian faktor:

Tabel 12. Penamaan Faktor Baru

\begin{tabular}{|c|c|c|c|}
\hline Nomor & $\begin{array}{l}\text { Nama } \\
\text { Faktor }\end{array}$ & Komponen Pembentuk & Nilai Varian Faktor \\
\hline 1 & $\begin{array}{l}\text { SDM dan } \\
\text { Pajak }\end{array}$ & $\begin{array}{l}\text { 1. Jumlah Ketersediaan Tenaga Kerja } \\
\text { 2. Pajak } \\
\text { 3. Pendidikan Tenaga Kerja }\end{array}$ & 34.278 \\
\hline 2 & Energi & $\begin{array}{ll}\text { 1. } & \text { Ketersediaan Air } \\
\text { 2. } & \text { Ketersediaan listrik } \\
\text { 3. } & \text { Harga Sewa Tempat Usaha }\end{array}$ & 20.573 \\
\hline 3 & Akses & Kemudahan lokasi untuk dikunjungi & 14.369 \\
\hline
\end{tabular}


Untuk mengetahui faktor yang berpengaruh dominan dilihat dari \% of variance eigenvalues tertinggi. Berdasarkan hasil pengelompokan faktor, diketahui bahwa faktor yang berpengaruh dominan dalam pemilihan lokasi usaha jasa di Kecamatan Paciran adalah faktor 1 yaitu SDM \& Pajak dengan varian yang menjelaskan sebesar $34,278 \%$.

Berdasarakan data diatas, interval setiap subvariabel dapat diketahui bahwa ada faktor yang penting dan ada juga yang sangat penting. Faktor penting terdiri dari faktor tenaga kerja, persaingan dan peraturan pemerintah sedangkan faktor yang dianggap sangat penting adalah faktor akses, fasilitas, pasar dan energi. Hal ini sama dengan penelitian Zuliarni dan Hidayat, yang menggunakan 5 faktor dalam penelitiannya. Hasil penelitian didapatkan ada 4 faktor yang dianggap sangat penting dan 1 faktor penting. Faktor sangat penting dalam pemilihan lokasi usaha tersebut adalah akses, visibilitas, lingkungan, tempat parkir. Sementara faktor lain yang dianggap penting bagi pemilik usaha adalah persaingan.

Hasil analisis data dapat diketahui melalui 2 kali reduksi jumlah indikator dari 20 direduksi hingga menjadi 7 indikator. Hal tersebut dilakukan untuk memenuhi persayaratan penggunaan analisis faktor. ketujuh indikator tersebut selanjutnya membentuk 3 faktor baru. Pemberian nama faktor dilakukan dengan melihat hasil dari perotasian.

Faktor pertama terbentuk dari indikator jumlah ketersediaan tenaga kerja, pajak dan pendidikan tenaga kerja dengan nama faktor adalah SDM \& Pajak. Faktor kedua terbentuk dari ketersediaan air, ketersediaan listrik dan harga sewa tempat usaha dengan nama faktor adalah Energi. Faktor ketiga dengan nama faktor Akses dengan indikator pembentuk kemudahan lokasi untuk dikunjungi.

Faktor pertama SDM dan Pajak sesuai Hidrayani (2010) yang mengemukakan bahwa salah satu faktor yang harus dipertimbangkan adalah SDM. Didukung oleh teori yang dikemukakan oleh Chase, et al (2006) yang menyatakan bahwa keputusan pemilihan lokasi usaha manufakturdan usaha jasa dipengaruhi oleh berbagai macam kriteria pemilihan yangmendasarkan pada kepentingan kompetitif. Diantaranya adalah pengaruh pajak yang ada pada lokasi usaha.

Hasil faktor kedua sama dengan yang disebutkan oleh Hidrayani (2010) bahwa energi adalah salah satu faktor yang harus dipertimbangkan dalam pemilihan lokasi usaha. Sedangkan faktor ketiga yakni akses, membantah hasil dari penelitian Sastrawan, (2015) dimana hasil penelitian menyatakan akses merupakan faktor yang paling dipertimbangkan dalam pemilihan lokasi usaha. Hal ini mungkin karena lokasi penelitian yang berbeda menyebabkan hasil yang berbeda.

Berdasarkan hasil analisis data diatas, untuk menentukan faktor yang paling mempengaruhi dilihat dari presentage of variance eigenvalues tertinggi. Berdasarkan hasil dari analisis faktor dapat diketahui bahwa faktor yang paling dipertimbangkan dalam pemilihan lokasi usaha jasa mikro-kecil- 
menengah yang berada di Kecamatan Paciran adalah faktor SDM dan Pajak.

\section{SIMPULAN}

Berdasarkan hasil analisis data dan pembahasan, maka dapat ditarik kesimpulan bahwa faktor lokasi: tenaga kerja, akses, fasilitas, pasar, energi, persaingan dan peraturan pemerintah menjadi pertimbangan dalam pemilihan lokasi usaha jasa yang ada di Kecamatan Paciran, Kabupaten Lamongan.

Dari ketujuh faktor tersebut,faktor akses, fasilitas, pasar dan energi masuk dalam kategori sangat penting. Sedangkan faktor tenaga kerja, persaingan dan peraturan pemerintah termasuk dalam kategori penting. Menurut hasil analisis, faktor yang paling dipertimbangkan oleh usaha jasa pada UMKM di Kecamatan Paciran adalah faktor SDM \& Pajak

\section{DAFTAR PUSTAKA}

Arikunto, S. 2003. Prosedur Penelitian, Suatu Praktek. Jakarta: Bina Aksara

Chase, et al. 2006. Operations Management for Competitive Advantage with Global Case. New York: Prentice Hall

Ghozali, I. 2005. Aplikasi Analisis Multivariate dengan program SPSS. Semarang: Badan Penerbit Universitas Diponegoro.

Handoko. H. 2000. Dasar-dasar Manajemen Produksi dan Operasi. Yogyakarta: BPFE.
Hidayat, A. 2014. Penjelasan Analisis Faktor (Factor Analysis) PCA danCFA.http://www.statistikian.c om/2014/03/analisisfaktor.html[diakses pada 2 Maret 2017]

Hindrayani, A. 2010. Manajemen Operasi. Yogyakarta: Pohon Cahaya.

Lupiyoadi, R. \& Hamdani, A. 2009. Manajemen Pemasaran Jasa, Edisi kedua. Jakarta: Salemba Empat.

Malhotra, N. K. 2006. Marketing research: An Apllied Orientation $\left(5^{\text {th }}\right.$ Edition). Upper Saddle River, NJ: Prentice Hall

Republik Indonesia. 2008. Undangundang nomor 20 tahun 2008 tentang Usaha Mikro Kecil dan Menengah.

Sanusi, A. 2011. Metode Penelitian Bisnis. Jakarta: Salemba Empat.

Sekaran, U. 2006. Metode Penelitian Untuk Bisnis. Jakarta: Salemba Empat

Tarigan, R. 2006. Ekonomi Regional: Teori dan Aplikasi (Edisi Revisi). Jakarta: Bumi Aksara.

Tjiptono, F. 2007. Pemasaran Jasa. Malang: Bayumedia Publishing.

Tjiptono, F. 2008. Strategi Pemasaran. Edisi ketiga. Yogyakarta: ANDI.

Umar, H. 2008. Metode penelitian untuk skripsi dan Tesis Bisnis. Jakarta: PT Raja Grafindo Persada

Widayat. 2004. Metode Penelitian Pemasaran. Malang: CV. Cahaya Pres 